\title{
Groundwater salinity mapping of the Belgian coastal zone to improve local freshwater storage availability
}

Dieter Vandevelde ${ }^{1}$, Esther van Baaren ${ }^{2}$, Joost Delsman ${ }^{2}$, Marios Karaoulis ${ }^{2}$, Gualbert Oude Essink $^{2,9}$, Perry de Louw ${ }^{2,8}$, Tommer Vermaas ${ }^{2}$, Pieter Pauw ${ }^{2}$, Marco de Kleine ${ }^{2}$, Sara

Thofte $^{3}$, Rasmus Teilmann ${ }^{3}$, Kristine Walraevens ${ }^{4}$, Marc Van Camp ${ }^{4}$; Huits Dominique ${ }^{5}$, Willem Dabekaussen ${ }^{6}$, Jan Gunnink ${ }^{6}$, Alexander Vandenbohede ${ }^{7}$

${ }^{1}$ Flanders Environment Agency (VMM), Brussels, Belgium

${ }^{2}$ Deltares, Utrecht, The Netherlands

${ }^{3}$ SkyTEM, Aarhus, Denmark

${ }^{4}$ Ghent University, Department of Geology, Belgium

${ }^{5}$ Inagro Knowledge Centre Water, Roeselare, Belgium

${ }^{6}$ Geological Survey of The Netherlands (TNO), The Netherlands

${ }^{7}$ De Watergroep, Brussel, Belgium

${ }^{8}$ Wageningen University \& Research, Wageningen, The Netherlands

${ }^{9}$ Utrecht University, Utrecht, The Netherlands

\begin{abstract}
In the European TOPSOIL project, countries around the North Sea are searching for solutions for climate related threats. They explore the possibilities of using the topsoil layer to solve current and future water challenges. The main objective is to improve the climate resilience of the water management of the topsoil and shallow aquifers in the North Sea region. TOPSOIL is supported by the Interreg VB North Sea Region program in line with priority 3 of the program: 'Sustainable North Sea Region, protecting against climate change and preserving the environment'.
\end{abstract}

The Belgian part of this project, called FRESHEM for GO-FRESH Vlaanderen ('FREsh Salt groundwater distribution by Helicopter ElectroMagnetic survey for Geohydrological Opportunities FRESH water supply'), focuses on mapping the salinity distribution of groundwater using airborne electromagnetics and aims to look into a number of measures that could increase the availability of freshwater for agriculture in the polder area. Two pilot projects will evaluate the possibilities for freshwater storage and aims to specify what measures can be taken to achieve this. Together with the other water users and water managers, The Flanders Environment Agency wants to prepare a plan for the realization of one or more pilot projects that can improve the availability of freshwater.

\section{INTRODUCTION}

Shallow coastal aquifers are vulnerable to climate change and sea-level rise (Cliwat, 2011; Ferguson \& Gleeson, 2012; Oude Essink et al., 2010; Vandenbohede et al., 2008). Some coastal regions in Europe are already dealing with an increased threat of drought and flooding (Faneca Sànchez et al., 2012; Giambastiani et al., 2007; Pauw et al., 2012; Rasmussen et al., 2013; Yang et al., 2015). Climate change and sea-level rise disturb the fragile balance between fresh and salt water and can lead to a more saline environment. The summer of 2017 for instance showed in the Belgian coastal plain how urgent water scarcity can be and how fast salinization of the fresh water surface water system can occur in polder areas. 
Farmers in West-Flanders (Belgium) make significant use of fresh groundwater from the confined Paleocene aquifer for their water supply. For years, the groundwater level of the Paleocene aquifer has been decreasing, compromising the security of water supply. In addition, shallow water resources are scarce because of the occurrence of brackish and saline water in the top aquifer near the coast, and the shallow occurrence of aquitards further inland. The TOPSOIL project will explore the possibilities of using the shallow aquifer to increase the availability of fresh groundwater.

The salinity distribution in the coastal plain was mapped by De Breuck et al. (1974 and 1989). To get an overview of the current situation of shallow water resources, the salinization of the coastal aquifer is reinvestigated by airborne electromagnetics. These results are used in a regional water system analysis where physical conditions, measures and potentials to improve the freshwater availability are investigated. This water system analysis will lead to regional maps showing potentials to apply specific measures to improve the freshwater availability.

\section{AIRBORNE SURVEY}

The fresh-salt water distribution of the coastal aquifers is mapped using the SkyTEM system (Figure 2) which is an airborne transient electromagnetic sensor that measures ground conductivity using electromagnetic waves (Auken et al., 2008; Schaars \& Rolf, 2014; Steuer et al., 2009; Viezzoli et al., 2009). The SkyTEM system delivers high resolution data of the subsurface resistivity thanks to a fast turn-off time and early time data, and a high signal to noise ratio. About 2400 line $\mathrm{km}$ are flown which covers the main part of the Belgian polder area (Figure 1). The inversion process produces bulk resistivity profiles for each flight line (Figure 3). With the aid of a lithological model, bulk resistivity will be converted into a 3D image of pore water resistivity and chloride concentrations. Finally, a map showing the distribution of porewater salinity of the area will be available.

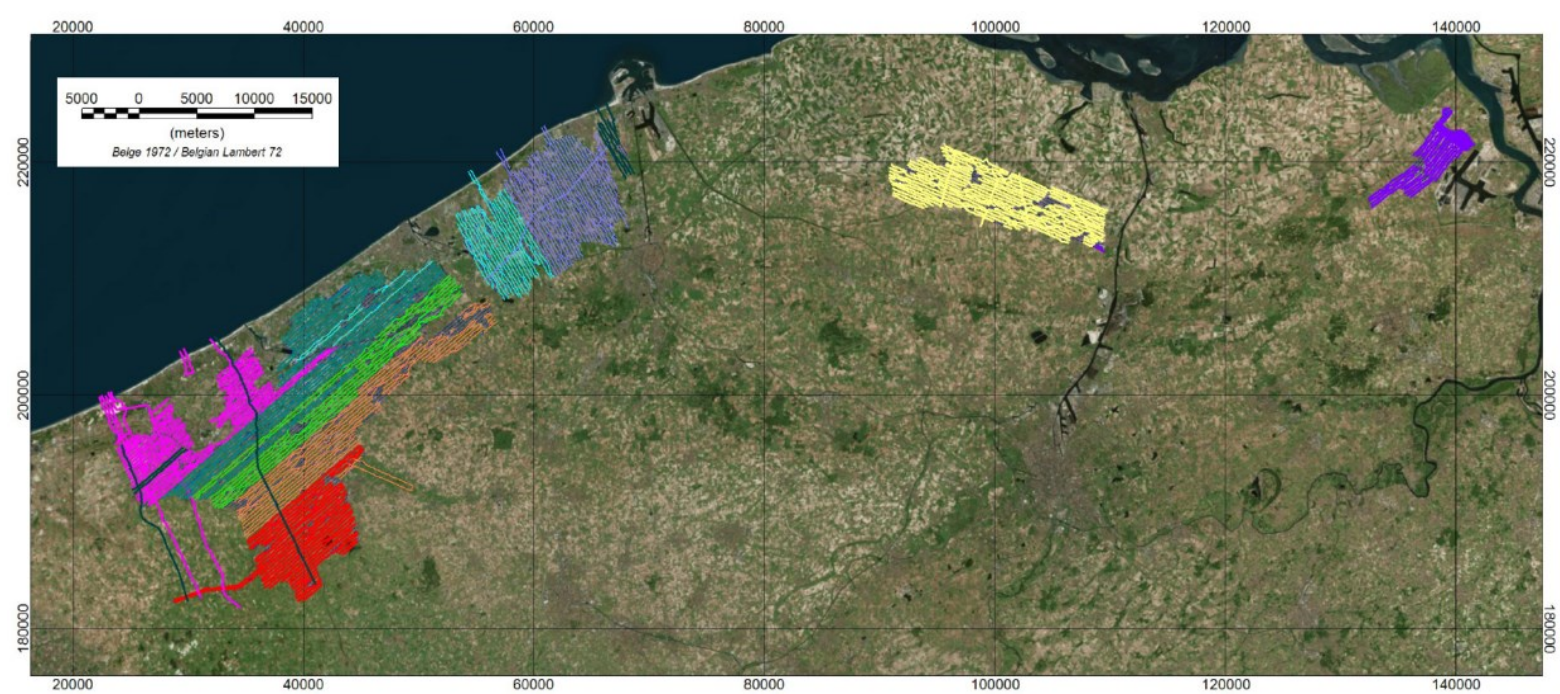

Figure 1. Flight lines (color coded on daily production).

The processed and inverted airborne electromagnetic data are verified by results of other hydrogeological research like recent groundwater analysis, borehole logs and SlimFlex measurements (flexible borehole electromagnetic soundings). Comparison will take place with data of vertical electrical soundings (VES). 


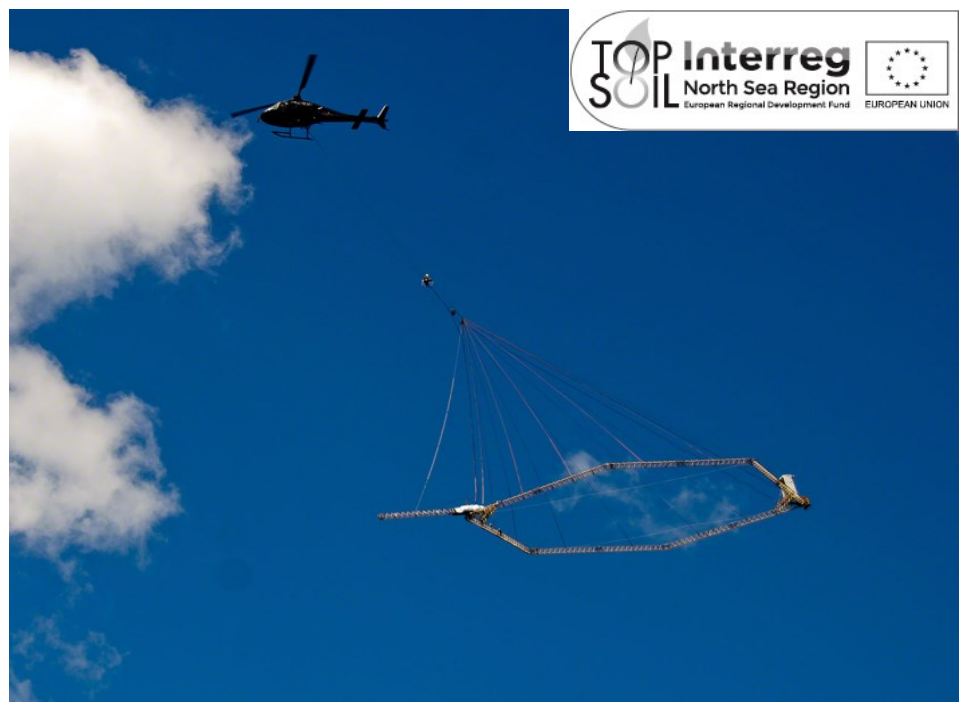

Figure 2. SkyTEM system

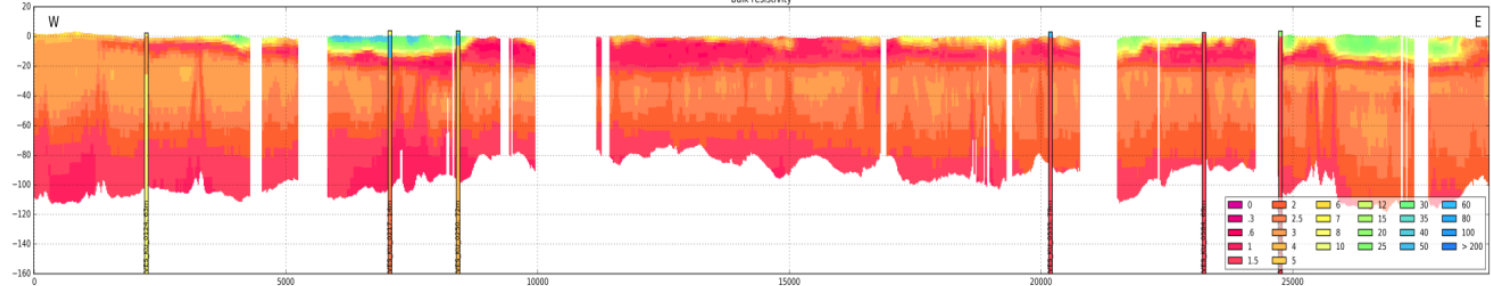

Figure 3. Bulk resistivity profile of flight line 103001 (Westcoast).

\section{IMPROVING THE FRESH-WATER AVAILABILITY}

The results of the airborne survey will be used to investigate the potential to improve the freshwater availability in the western polder area. The consortium (Deltares, Ghent University, TNO, Inagro, De Watergroep) has already a lot of experience with these kind of measures (van Baaren et al., 2015, 2018; Bironne et al., 2017; Delsman et al., 2015, 2017, 2018; Oude Essink et al., 2014; Pauw et al., 2015). This experience will be used to select the most appropriate measures for the study area. The following steps are distinguished:

\section{Water system analysis}

The current fresh-salt water distribution and the possibilities to increase the existing freshwater lenses, are determined by physical conditions (hydrogeology, topography) as well as human conditions (drainage systems, groundwater extractions). The water system analysis will collect all necessary data and will determine relationships between those conditions. Possible measures will be listed. For each measure boundary, conditions will be defined together with the benefits and disadvantages. The water system analysis will finally lead to a map which shows the potential to apply a certain kind of measure.

\section{Stakeholder participation}

By consulting local stakeholders about their current and future needs we will get an idea of the water availability, water use and water demand today and in the near future. It will also give insight into how realistic the implementation of a certain measure will be. The key to a successful implementation of measures lies in fostering support through participation. 


\section{Pilot areas}

For a selected area, the most appropriate measures will be withheld. For these measures, a financial analysis will be made (costs and benefits). In consultation with stakeholders, two pilot areas will be selected and an implementation plan will be made. The realization of these pilot projects will serve as model projects for future investigations.

\section{CONCLUSIONS}

The Belgian part of the TOPSOIL project explores the possibilities of using the shallow aquifer to increase the availability of fresh groundwater for agriculture. An airborne electromagnetic survey (SkyTEM) updates information about the current situation of fresh groundwater reserves in the coastal aquifer. The output of this airborne survey will serve as basic information for a water system analysis. This analysis leads to a map which shows the potential to apply a certain kind of measure to improve the freshwater availability. Together with stakeholders, pilot areas will be selected and will serve as model projects to future investigations.

\section{REFERENCES}

Auken, E., Christiansen, A. V., Jacobsen, L. H., \& Sørensen, K. I. 2008. A resolution study of buried valleys using laterally constrained inversion of TEM data. Journal of Applied Geophysics, 65(1), 10 20. https://doi.org/10.1016/j.jappgeo.2008.03.003

Van Baaren, E. S., Delsman, J. R., Karaoulis, M., Pauw, P. S., Vermaas, T., Bootsma, H., ... Meyer, U. 2018. FRESHEM Zeeland - FREsh Salt groundwater distribution by Helicopter ElectroMagnetic survey in the Province of Zeeland. Deltares report 1209220. Utrecht, Netherlands.

van Baaren, E. S., De Lange, G., Vermeulen, P. T. M., \& Vonhögen - Peeters, L. 2015. Exploring groundwater resources on Jurong Island, Singapore; Monitoring, modelling and assessing risks (PUB report).

Bironne, A., Saha, A., Lee, W. K., Babovic, V., Vonhogen, L., van Baaren, E. S., ... Hoogendoorn, B. 2017. Utilization of reclaimed land as groundwater reservoir. In 14th Annual Meeting Asia Oceania Gesciences Society, 6-11 Augustus.

De Breuck, W., De Moor, G., Maréchal, R., \& Tavernier, R. 1974. Diepte van het grensvlak tussen zoet en zout water in de freatische laag van het Belgische kustgebied (1963-1973). Verziltingskaart. Brussel, Militair Geografisch Instituut.

De Breuck, W., De Moor, G., Maréchal, R. \& Tavernier R. 1989. Diepte van het grensvlak tussen zoet en zout water in de freatische watervoerende laag van noordelijk Vlaanderen (1974-1975). Cliwat. (2011). Groundwater in a Future Climate.

Delsman, J. R., De Paz, J. M., De Klerk, M., Stuyt, L., De Louw, P. G. B., Visconti, F., ... Pecora, S. 2015. Application of the FWOO method in the Vega Baja Segura catchment Application of the FWOO method in the Vega Baja Segura catchment. Deltares Rapport 1220325, 98.

Delsman, J. R., Van Baaren, E. S., Karaoulis, M., Pauw, P. S., Vermaas, T., Bootsma, H., ... Revil, A. 2018. Large-scale, probabilistic airborne EM mapping provides detailed view of groundwater salinity in the province of Zeeland, Netherlands. To Be Submitted to Environmental Research Letters.

Delsman, J. R., Boekel, E. Van, Reinhard, S., Van Loon, A., Bartholomeus, R., Mulder, M., ... 
Schasfoort, F. 2017. Regioscan Zoetwatermaatregelen, Verkennen van het perspectief van kleinschalige zoetwatermaatregelen voor de regionale zoetwateropgave.

Faneca Sànchez, M., Gunnink, J. L., van Baaren, E. S., Oude Essink, G. H. P., Auken, E., Elderhorst, W., \& De Louw, P. G. B. 2012. Modelling climate change effects on a Dutch coastal groundwater system using airborne electromagnetic measurements. Hydrology and Earth System Sciences, 16(12), 4499-4516. https://doi.org/10.5194/hess-16-4499-2012

Ferguson, G., \& Gleeson, T. 2012. Vulnerability of coastal aquifers to groundwater use and climate change. Nature Climate Change, 2(5), 342-345. https://doi.org/10.1038/nclimate1413

Giambastiani, B. M. S., Antonellini, M., Oude Essink, G. H. P., \& Stuurman, R. J. 2007. Saltwater intrusion in the unconfined coastal aquifer of Ravenna (Italy): A numerical model. Journal of Hydrology, 340(1-2), 91-104. https://doi.org/10.1016/j.jhydrol.2007.04.001

Oude Essink, G. H. P., van Baaren, E. S., \& De Louw, P. G. B. 2010. Effects of climate change on coastal groundwater systems: A modeling study in the Netherlands. Water Resources Research, 46(May), 1-16. https://doi.org/10.1029/2009WR008719

Oude Essink, G. H. P., Van Baaren, E. S., Zuurbier, K. G., Velstra, J., Veraart, J., Brouwer, W., ... Schroevers, M. 2014. GO-FRESH: Valorisatie kansrijke oplossingen voor robuuste zoetwatervoorziening, KvK rapport (in Dutch).

Pauw, P. S., De Louw, P. G. B., \& Oude Essink, G. H. P. 2012. Groundwater salinisation in the Wadden Sea area of the Netherlands: quantifying the effects of climate change, sea-level rise and anthropogenic interferences. Netherlands Journal of Geosciences - Geologie En Mijnbouw, 91-3(3), 373-383. https://doi.org/10.1017/S0016774600000500

Pauw, P. S., Van Baaren, E. S., Visser, M., De Louw, P. G. B., \& Oude Essink, G. H. P. 2015. Increasing a freshwater lens below a creek ridge using a controlled artificial recharge and drainage system: a case study in the Netherlands. Hydrogeology Journal. https://doi.org/10.1007/s10040-015$1264-\mathrm{z}$

Rasmussen, P., Sonnenborg, T. O., Goncear, G., \& Hinsby, K. 2013. Assessing impacts of climate change, sea level rise, and drainage canals on saltwater intrusion to coastal aquifer. Hydrology and Earth System Sciences, 17(1), 421-443. https://doi.org/10.5194/hess-17-421-2013

Schaars, F., \& Rolf, H. 2014. SkyTEM PWN: Eindrapportage van het airborne geofysisch onderzoek Noordhollands Duinreservaat PWN.

Steuer, A., Siemon, B., \& Auken, E. 2009. A comparison of helicopter-borne electromagnetics in frequency- and time-domain at the Cuxhaven valley in Northern Germany. Journal of Applied Geophysics, 67(3), 194-205. https://doi.org/10.1016/j.jappgeo.2007.07.001

Vandenbohede, A., Luyten, K., \& Lebbe, L. C. 2008. Effects of Global Change on Heterogeneous Coastal Aquifers: A Case Study in Belgium. Journal of Coastal Research, 24, 160-170. https://doi.org/10.2112/05-0447.1

Viezzoli, A., Auken, E., \& Munday, T. 2009. Spatially constrained inversion for quasi 3D modelling of airborne electromagnetic data an application for environmental assessment in the Lower Murray Region of South Australia. Exploration Geophysics, 40(2), 173-183. https://doi.org/10.1071/EG08027 
Yang, J., Graf, T., \& Ptak, T. 2015. Impact of climate change on freshwater resources in a heterogeneous coastal aquifer of Bremerhaven, Germany: A three-dimensional modeling study. Journal of Contaminant Hydrology, 177-178, 107-121.

https://doi.org/10.1016/j.jconhyd.2015.03.014

Contact Information: Dieter Vandevelde, Flanders Environment Agency, Koning Albert II-laan 20, 1000 Brussels, Belgium, Phone: +32 221421 27,

Email: di.vandevelde@vmm.be 